\begin{tabular}{lcccc|cr} 
Volume & 13, & Nomor 1, & Mei 2021, & pp 61-71 & \multicolumn{2}{c}{ Copyright $@ 2017$} \\
Jurnal & Akuntansi, & Program & Studi & Akuntansi, & Fakultas & Bisnis, \\
Universitas & Kristen & Maranatha. & ISSN & $2085-8698$ & e-ISSN & $2598-4977$.
\end{tabular}

http://journal.maranatha.edu

\title{
Analisis Pencatatan dan Pelaporan PSAK 45 di Gereja X Salatiga
}

\author{
Edni Olka Pratiwi ${ }^{1}$ \\ Universitas Kristen Satya Wacana \\ (Jl. Diponegoro No. 52-60, Salatiga) \\ edniolka@gmail.com \\ Ika Kristianti ${ }^{2}$ \\ Universitas Kristen Satya Wacana \\ (Jl. Diponegoro No. 52-60, Salatiga) \\ ika.kristianti@uksw.edu
}

\begin{abstract}
Indonesia has already had an accounting standard for their non-profit organization, This standart are written in PSAK 45 about financial reporting for non-profit organization. This research are done in Gereja X Salatiga as a non-profit organization in religious organization. Aim of this research is to analyze application of PSAK 45 in Gereja X Salatiga financial report. This research is expected to help evaluate financial reporting in Gereja X Salatiga. Method used in this research are descriptive qualitative to describe, decipher and compare data with circumstances and also explain such a situation so conclusions can be drawn. The results of this research is Gereja X Salatiga has implementing and using financial report suitable with PSAK 45, although its format are not following the format given by Indonesian Accounting Association, but generally has reached its aim to report their financial process. Report shown to congregation are cash receipt and cash disbursement reports, and also a church expenditure receipt budget report.
\end{abstract}

Keywords: PSAK 45, Non-profit Organization

\begin{abstract}
Abstrak
Indonesia telah menetapkan standar akuntansi untuk organisasi nirlaba. Standar ini tertera dalam PSAK 45 tentang pelaporan keuangan organisasi nirlaba. Penelitian ini dilakukan pada Gereja X Salatiga yang merupakan salah satu organisasi nirlaba dalam bidang lembaga keagamaan. Penelitian ini bertujuan untuk menganalisis penerapan PSAK 45 pada laporan keuangan Gereja X Salatiga. Penelitian ini diharapkan dapat membantu dan mengevaluasi pencatatan laporan keuangan di Gereja X Salatiga. Metode analisis yang digunakan adalah
\end{abstract}


metode kualitatif deskriptif yang sifatnya menggambarkan, menguraikan, dan membandingkan data dengan keadaan serta menerangkan suatu keadaan sedemikian rupa sehingga dapat ditarik sebuah kesimpulan. Hasil dan kesimpulan dari penelitian ini adalah Gereja X Salatiga sudah menerapkan dan membuat laporan keuangan yang sesuai dengan PSAK 45, walaupun format laporan keuangan tidak mengikuti format laporan keuangan yang ditetapkan oleh Ikatan Akuntansi Indonesia, namun secara umum tujuan laporan keuangan Gereja X Salatiga telah tercapai. Laporan yang disajikan kepada jemaat adalah laporan penerimaan dan pengeluaran kas, serta laporan Anggaran Penerimaan Belanja Gereja.

\section{Kata Kunci : PSAK 45, Organisasi Nirlaba}

\section{Pendahuluan}

Indonesia adalah salah satu negara berkembang yang memiliki beberapa masalah di beberapa sektor terutama dalam perekonomiannya (Tunungki \& Pusung, 2014). Menurut Pontoh (2013), kemajuan Ilmu Pengetahuan dan Teknologi (IPTEK) di Indonesia membawa perubahan terutama pada bidang ekonomi. Perkembangan IPTEK di Indonesia pada kenyataannya masih belum mampu menyelesaikan masalah-masalah yang ada sehingga terciptalah organisasi nirlaba. Organisasi yang dalam praktik usahanya tidak untuk mencari keuntungan dikategorikan sebagai organisasi nirlaba, sebagai contohnya adalah lembaga keagamaan dan yayasan pendidikan (Jusuf, 2005). Pandangan para pelanggan, donatur, sukarelawan, pemerintah, anggota dan karyawan dalam organisasi nirlaba sangat berbeda dengan organisasi komersial. Para pengurusnya sudah terseleksi dengan ideal, dengan tujuan yang tulus untuk mendukung organisasi, agar mencapai tujuannya, meskipun dalam kenyataannya tidak demikian (Liadi, 2011).

Organisasi nirlaba perlu membuat laporan keuangan sebagai bentuk tanggungjawab atas kegiatan organisasi selama satu periode. Menurut Yuliarti (2014), informasi pada laporan keuangan sangat diperlukan dalam pemenuhan kepentingan pengguna laporan keuangan tersebut. Agar dapat memenuhi kepentingan pengguna laporan keuangan, diperlukannya laporan keuangan yang transparan dan

accountable, maka dari itu PSAK 45 di Indonesia disusun untuk mengatur penyusunan laporan keuangan organisasi nirlaba (Gultom \& Poputra, 2015). Menurut Nikmatuniayah (2014) dan Yuliarti (2014), organisasi nirlaba harus menyediakan laporan keuangan dengan format sesuai PSAK 45. Namun, dalam praktiknya masih banyak organisasi nirlaba yang hanya melakukan pencatatan keuangan tetapi tidak disertai jumlah aset yang dimiliki dan hanya terdiri dari laporan penerimaan dan pengeluaran kas saja (Andarsari, 2017).

Untuk organisasi nirlaba di internasional masih membutuhkan standar baru, karena International Financial Reporting Standards (IFRS) maupun International Public Sector Accounting Standards (IPSAS) tidak cocok diterapkan untuk organisasi nirlaba (C. J. Cordery, Crawford, Breen, \& Morgan, 2019). Inggris, Belanda, Hongkong, New Zealand mengacu pada IFRS. Inggris dan Belanda mengacu pada sector-specific financial reporting regulations. New Zealand, mengacu pada sector-natural standars tetapi tidak mengadopsi IFRS, sedangkan Hongkong tidak mengacu pada kedua sektor tersebut (Cordery, 2015). Menurut Roslan, Arshad, dan Pauzi (2017), Malaysia tidak memiliki standar untuk organisasi nirlaba, jadi dalam pelaporannya menggunakan standar pelaporan entitas bisnis, sedangkan Australia sudah mengeluarkan guidelines 
untuk pelaporan nirlaba. Inggris dan Irlandia pada tahu 2013 sudah mengeluarkan Statement of Recommended Practice (SORP) untuk membantu nirlaba dalam pembuatan laporan keuangannya, dan untuk organisasi nirlaba di Canada menggunakan CICA Handbook and Financial Information Kit pada tahun 2010 (Roslan et al., 2017).

Pernyataan Standar Akuntansi Keuangan (PSAK) 45 adalah peraturan tentang penyusunan laporan keuangan organisasi nirlaba (Dinanti \& Nugraha, 2018). PSAK 45 memuat pengertian tentang tujuan laporan keuangan organisasi nirlaba. Penyajian laporan keuangan organisasi nirlaba bertujuan untuk memberi informasi terkait tentang organisasi nirlaba yang sesuai dalam upaya pemenuhan kepentingan donatur, kreditur, anggota organisasi, serta pihak lain yang ikut serta dalam memberikan sumber daya di organisasi tersebut (Yuda, 2016). PSAK 45 menetapkan bahwa setiap tahunnya organisasi nirlaba wajib membuat 4 (empat) laporan keuangan, yaitu laporan posisi keuangan, laporan aktivitas, laporan arus kas, dan catatan atas laporan keuangan (CALK). Penyusunan laporan keuangan bagi organisasi nirlaba juga harus memisahkan sifat pembatas dana. Menurut PSAK 45 terdapat 4 (empat) jenis pembatasan dana, yaitu pembatasan temporer, pembatasan permanen, sumbangan yang bersifat terikat, serta sumbangan yang sifatnya tidak terikat (Yuda, 2016).

Gereja yang merupakan salah satu organisasi nirlaba, sesuai dengan peraturan PSAK 45, organisasi nirlaba diwajibkan untuk membuat laporan keuangan. Gereja X Salatiga merupakan salah satu gereja tertua yang berada di Salatiga, dengan jumlah jemaat hampir mencapai 1000 warga jemaat. Saat ini Gereja X Salatiga sudah membuat laporan keuangan seperti yang ditetapkan PSAK 45, namun tidak semua laporan keuangan diinformasikan kepada jemaat. Laporan yang diinformasikan kepada jemaat hanyalah laporan penerimaan dan pengeluaran kas yang dilampirkan pada warta gereja setiap minggunya. Laporan keuangan gereja sudah dibuat dengan sederhana, sehingga perlu diteliti kembali kesesuaian antara laporan keuangan Gereja $X$ Salatiga dengan PSAK 45.

Dari uraian tersebut, maka timbul persoalan penelitian; (1) apakah pencatatan dan pelaporan yang dibuat Gereja X Salatiga sudah sesuai dengan PSAK 45?; dan (2) bagaimana penerapan PSAK 45 di Gereja X Salatiga? Tujuan dari penelitian ini adalah untuk menganalisis penerapan PSAK 45 pada laporan keuangan Gereja X Salatiga. Penelitian ini diharapkan dapat membantu dan mengevaluasi pencatatan laporan keuangan di Gereja X Salatiga.

\section{Kerangka Teoretis dan Hipotesis}

\section{Organisasi Nirlaba}

Torang (2013) menyatakan bahwa organisasi adalah sistem peran, pola hubungan kerja yang melibatkan sekumpulan orang sebagai pelaksana tugas yang dirancang dalam upaya pencapaian tujuan bersama. Nirlaba adalah bentuk penggambaran dari segala hal yang bertujuan sosial dan tidak bertujuan untuk mencari laba. Jadi, organisasi nirlaba merupakan organisasi sosial dengan tujuan untuk menarik masyarakat dengan tujuan tidak komersil, tanpa adanya maksud untuk mencari keuntungan (Tunungki \& Pusung, 2014). Contoh organisasi nirlaba ialah lembaga keagamaan, rumah sakit, lembaga pendidikan, rumah sakit, dan organisasi politik. Salah satu organisasi nirlaba dalam bidang keagamaan adalah gereja (Pontoh, 2013). Pengertian gereja secara umum adalah perkumpulan umat kristiani atau tempat ibadah umat kristen. Gereja hanya mendapatkan sumber dana dari persembahan mingguan, perpuluhan, dan persembahanpersembahan lainnya.

Menurut Fatin (2017) terdapat tiga karakteristik organisasi nirlaba yaitu; (1) Sumber daya organisasi bersumber dari para donatur yang tidak mengharapkan 
keuntungan yang sebanding dengan sumber daya yang telah diberikan; (2) menghasilkan barang atau jasa tanpa tujuan untuk memperoleh laba, dan bila organisasi nirlaba memperoleh laba pada periode akuntansi berjalan, maka labanya tidak dibagikan kepada pemilik organisasi maupun para donatur; (3) tidak adanya kepemilikan seperti halnya dalam organisasi bisnis, dalam hal ini berarti kepemilikan organisasi nirlaba tidak mencerminkan proporsi pembagian modal organisasi pada saat pembubaran organisasi. Adapun jenis dana pada organisasi nirlaba tergantung dengan karakteristik organisasinya, namun jika dilihat dari ketersediaan batasan dari donatur maka jenis data dapat dibagi menjadi tiga, yaitu; (1) terikat secara permanen, yaitu adanya batasan penggunaan dana oleh donatur agar dana dipertahankan secara permanen; (2) terikat temporer, yaitu adanya batasan dana oleh donatur yang menentukan bahwa dana tersebut hanya sampai dengan akhir periode tertentu; (3) tidak terikat, yaitu dana yang diberikan tanpa syarat tertentu (Fatin, 2017).

\section{PSAK No. 45}

PSAK 45 yang ditetapkan oleh Ikatan Akuntan Indonesia (IAI) berisikan unsurunsur dan tujuan pada proses pelaporan keuangan organisasi nirlaba, yaitu: laporan posisi keuangan sama dengan neraca laporan keuangan organisasi komersial. Laporan posisi keuangan berisikan informasi tentang jumlah aktiva dan hutang organisasi pada satu periode tertentu. Laporan posisi keuangan bertujuan untuk memberikan informasi tentang aktiva, kewajiban, dan aktiva bersih, serta memberikan informasi tentang hubungan antar akun-akun tersebut dalam periode tertentu. Informasi yang disediakan pada laporan posisi keuangan bila digunakan dengan laporan keuangan yang lain dapat menjadi acuan bagi para donatur, anggota, kreditur, serta pihak lain dalam proses penilaian kemampuan sebuah organisasi nirlaba.
Laporan aktivitas terbagi menjadi dua bagian, yaitu bagian pendapatan dan bagian biaya organisasi dalam satu periode anggaran. Bagian pendapatan dibagi berdasarkan ikatan yang ada dan bagian biaya digolongkan berdasarkan kriteria fungsional. Tujuan dari laporan aktivitas adalah memberikan informasi tentang pengaruh transaksi dengan aktivitas lainnya yang mengakibatkan perubahan dalam sifat dan jumlah aktiva bersih organisasi, hubungan transaksi satu dengan yang lain dan aktivitas lain, serta pemakaian sumber daya organisasi dalam pelaksanaan aktivitasnya. Informasi dalam laporan aktivitas jika digunakan bersamaan dengan laporan keuangan yang lain bisa menjadi acuan para donatur, anggota, kreditur, serta pihak lain dalam proses evaluasi kinerja organisasi dalam satu periode, penilaian upaya, kemampuan dan kesinambungan organisasi, serta penilaian pelaksanaan tugas dan kinerja manajer.

Laporan arus kas ini mencatat aliran kas masuk dan kas keluar suatu organisasi dalam satu periode. Periode dalam laporan arus kas sama dengan periode dalam laporan aktivitas. Dalam pencatatan arus kas masuk dan kas keluar harus dipisahkan menjadi tiga aktivitas, yaitu: (a) Aktivitas operasi, dalam aktivitas ini, pemasukan dan pengeluaran kas yang digunakan untuk aktivitas operasi organisasi; (b) Aktivitas Investasi yang berisikan penambahan dan pengurangan kas yang digunakan untuk investasi organisasi. Investasi tersebut dapat berupa pinjaman, pembelian/penjualan aset organisasi, dan pencairan dana. (c) Aktivitas Pendanaan, pencatatan atau pelunasan hutang organisasi, serta kenaikan atau penurunan aktiva bersih dari surplus atau defisit. Tujuan pelaporan arus kas adalah untuk memberikan informasi tentang penerimaan atau pengeluaran kas organisasi dalam satu periode.

Catatan atas laporan keuangan (CALK) merupakan bagian yang tidak dapat dipisahkan dari laporan keuangan yang lain dengan tujuan agar semua informasi 
keuangan organisasi yang dianggap perlu diketahui penggunanya sudah digunakan. Tujuan penyusunan CALK menurut Tunungki dan Pusung (2016) adalah untuk memberikan informasi berupa: (a) jumlah dan sifat aktiva, liabilitas, dan aktiva neto entitas nirlaba; (b) pengaruh transaksi, peristiwa, dan situasi lainnya yang mengubah nilai dan sifat aktiva neto; (c) jenis dan jumlah arus masuk dan arus keluar sumber daya dalam satu periode dan hubungan antara keduanya; (d) cara entitas nirlaba mendapatkan dan membelanjakan kas, memperoleh pinjaman dan melunasi pinjaman, dan faktor lainnya yang berpengaruh pada likuiditasnya; (e) usaha entitas nirlaba.

\section{Penelitian Terdahulu}

Dalam penelitian sebelumnya oleh Mamesah (2013), GMIM Efrata Sentrum Sonder membuat laporan keuangan menurut dengan pedoman Tata Gereja-gereja Masehi Injili di Minahasa (GMIM). Hal ini menyatakan bahwa GMIM Efrata Sentrum Sonder belum menerapkan PSAK 45 pada penyusunan laporan keuangannya. Penelitian Gultom dan Poputra (2015) menyebutkan bahwa Sinode GMIM belum menerapkan PSAK 45 dalam pelaporan keuangannya. Kantor Sinode GMIM membuat laporan keuangan berupa laporan realisasi anggaran belanja dan laporan pendapatan. Laporan tersebut dibuat menurut tata gereja sinode GMIM dan diterbitkan dan 2 (dua) kali dalam satu tahun, serta dipertanggungjawabkan dalam sidang majelis sinode GMIM. Sedangkan menurut Pontoh (2013), Gereja Bukit Zaitun membuat laporan keuangan berdasarkan Tata Dasar dan Peraturan Gereja, yang berarti Gereja Bukit Zaitun belum menerapkan PSAK 45 dalam pelaporan keuangannya.

\section{Metode Penelitian}

\section{Jenis Penlitian dan Teknik Pengumpulan Data}

Penelitian ini menggunakan metode kualitatif deskriptif yang bersifat menggambarkan, menguraikan, dan membandingkan data dengan keadaan serta menerangkan suatu keadaan sedemikian rupa sehingga dapat ditarik sebuah kesimpulan. Metode kualitatif deskriptif digunakan karena memungkinkan peneliti untuk menganalisis informasi serta mengidentifikasi karakteristik yang terkandung dalam teks tersebut (Scherp, 2013; Sousa, 2014; U. Sekaran \& R. Bougie, 2016). Data diperoleh dari wawancara dan observasi. Teknik pengumpulan data dilakukan dengan mengumpulkan data laporan keuangan Gereja X melalui: (a) wawancara, yaitu teknik pengumpulan data dengan cara tanya jawab langsung pada pihak-pihak yang berkepentingan; (b) survei lapangan, yaitu pengamatan langsung ke objek penelitian untuk memeroleh dan mencatat data-data yang diperlukan. Indrianto dan Supomo, (2013:12) membedakan data menjadi dua, yaitu: (a) data kuantitatif yang menekankan pada teori pengukuran variabel-variabel menggunakan angka dan menganalisis data dengan prosedur statistik; (b) data kualitatif yang menekankan pada pemahaman masalahmasalah di kehidupan sosial berdasarkan kondisi realitas, holistis, kompleks dan rinci.

\section{Teknik Analisis}

Teknik analisis dalam penelitian ini menggunakan tiga tahapan analisis yaitu reduksi, penyajian data, dan pengambilan kesimpulan. Tahap reduksi data ini digunakan untuk menyederhanakan data, menyeleksi data, dan membuat ringkasan atas data yang telah didapatkan selama proses pengumpulan data pada penyusunan laporan keuangan Gereja X Salatiga. Tahap reduksi data ini digunakan agar bisa memilah data-data yang tidak diperlukan sehingga bisa mendapatkan data-data 
penting dan bermanfaat untuk penelitian ini. Selanjutnya tahap penyajian data yang merupakan tindak lanjut dari tahap reduksi data. Dalam tahap penyajian data ini, datadata sebelumnya yang telah diseleksi dan disederhanakan akan disusun menjadi teks naratif, sehigga mempermudah untuk tahap pengambilan kesimpulan. Dalam tahap penyajian data ini menggambarkan keadaan laporan keuangan di Gereja X Salatiga.

Penelitian ini juga menggunakan tahap triangulasi, yaitu melakukan wawancara terhadap: (1) Pendeta Gereja X Salatiga; (2) Majelis bagian keuangan Gereja X Salatiga; (3) Karyawan bagian administrasi Gereja X Salatiga; dan (4) Jemaat Gereja X Salatiga. Bersamaan dengan dilakukannya wawancara, penelitian ini juga melakukan dokumentasi dengan mengumpulkan dokumen-dokumen pendukung yaitu laporan keuangan Gereja X Salatiga. Dalam wawancara kepada narasumber, penelitian ini melakukan konfirmasi hasil wawancara dari setiap narasumber. Konfirmasi ini dilakukan untuk memastikan hasil dari wawancara yang dilakukan. Setelah melakukan wawancara, peneliti melakukan observasi terhadap tata cara pencatatan dan pelaporan serta dokumentasi atas laporan yang telah dibuat oleh pihak gereja. Tujuan dari observasi dan dokumentasi adalah untuk memastikan antara hasil wawancara yang telah dilakukan sudah sesuai dengan pencatatan laporan keuangan atau belum.

\section{Hasil Penelitian dan Pembahasan}

\section{Sistem Pelaporan Keuangan Gereja}

Berdasarkan informasi yang diperoleh melalui wawancara dengan narasumber, GEREJA $X$ Salatiga menganut sistem sentralisasi. Sistem sentralisasi memusatkan semua keuangan yang diterima melalui persembahan mingguan, persembahan khusus, persembahan perpuluhan, pralenan, bunga bank, pendapatan sewa gedung, dan uang parkir secara bersama di rekening gereja. Sentralisasi dilakukan sebagai bentuk upaya pencegahan adanya pemupukan keuangan gereja dan sebagai bentuk pengamanan keuangan gereja.

\section{Pencatatan Laporan Keuangan Gereja}

Gereja X Salatiga melakukan pencatatan dengan dasar cash basis dalam setiap pencatatan transaksinya, yang berarti pencatatan dilakukan pada saat terjadinya penerimaan dan pengeluaran kas. Gereja X Salatiga melakukan penjurnalan secara batch dengan rekening Bank sebagai lawan jurnalnya. Contohnya ketika terjadi pengeluaran kas untuk kegiatan persekutuan komisi-komisi di Gereja.

Gereja X Salatiga setiap tahunnya membuat Rencana Anggaran Penerimaan dan Belanja Gereja (RAPBG). RAPBG dibuat oleh setiap komisi di gereja yang berisikan rencana kegiatan dan anggaran yang dibutuhkan komisi dalam satu tahun. Dana yang dapat dikeluarkan dari kas gereja hanyalah dana yang tercantum dalam RAPBG. Setiap komisi harus membuat Surat Permintaan Realisasi Anggaran (SPRA) untuk mencairkan dana yang sudah dianggarkan. Jika dana yang dianggarkan kurang maka komisi melakukan usaha dana (USDA) untuk menutupi kekurangan dana tersebut, namun jika dana yang dianggarkan lebih besar dari yang direalisasikan, maka kelebihan dana tersebut dikembalikan kepada gereja. Gereja juga menginformasikan laporan RAPBG kepada jemaat setiap tahunnya. Hal ini didukung oleh kutipan wawancara dengan bendahara dan PHM Gereja X Salatiga sebagai berikut: "Gereja membuat RAPBG setiap tahunnya, dan untuk mencairkan dana RAPBG maka setiap komisi harus membuat SPRA. Jika dana yang diperoleh komisi kurang, komisi melakukan usaha untuk menutupi kekurangan dana tersebut."

Gereja X Salatiga selalu memberikan laporan keuangan gereja yang tercantum dalam warta jemaat pada setiap minggunya. Laporan keuangan gereja yang disampaikan 
berisi laporan penerimaan dan pengeluaran kas gereja. Hal ini didukung oleh kutipan wawancara dengan pendeta dan jemaat Gereja X Salatiga sebagai berikut:

"Setiap minggunya jemaat dapat informasi laporan penerimaan dan pengeluaran kas saja yang tertera dalam warta jemaat."

Selain itu, gereja juga membuat laporan keuangan sesuai PSAK 45 yaitu laporan posisi keuangan, laporan aktivitas keuangan, laporan arus kas, dan CALK. Laporan keuangan gereja dibuat oleh karyawan administrasi gereja. Hal tersebut didukung oleh bukti wawancara dengan bendahara dan PHM Gereja X Salatiga sebagai berikut:

"Kami membuat sesuai dengan PSAK. Kami membuat laporan keuangan sampai dengan neraca."

Gereja mendapatkan sumber dana dari persembahan dan non-persembahan. Dana yang bersumber dari persembahan seperti persembahan mingguan, persembahan khusus, persembahan perpuluhan, dan pralenan. Dana yang tidak bersumber dari persembahan seperti pendapatan bunga bank, pendapatan sewa gedung, dan uang parkir. Dana yang diperoleh dari persembahan dihitung dan dicatat oleh majelis yang bertugas pada hari Minggu setelah kebaktian, dan dihitung kembali pada hari Senin oleh komisi keuangan, lalu pada hari yang sama, uang itu disetorkan ke bank oleh bendahara majelis. Hal tersebut didukung oleh kutipan wawancara dengan bendahara dan PHM Gereja X Salatiga sebagai berikut:

"Jadi, setiap hari setelah ibadah, majelis yang bertugas menghitung uang persembahan lalu dicatat dan dimasukkan dalam brankas. Hari Seninnya, komisi keuangan menghitung ulang uang persembahan tersebut lalu pada hari yang sama juga disetor ke bank."

Dana yang diperoleh dari persembahan mingguan, persembahan khusus, perpuluhan dan persembahan lainnya termasuk dari donatur dicatat sebagai persembahan dalam rekening bank yang terpisah sesuai dengan sumber dananya. Persembahan pralenan yang digunakan untuk kedukaan dicatat terpisah dan di rekening yang berbeda.

\section{Pembahasan \\ Pencatatan Laporan Keuangan}

Gereja X Salatiga melakukan pencatatan dengan dasar cash basis dalam setiap pencatatan transaksinya, yang berarti pencatatan hanya dilakukan pada saat terjadinya penerimaan dan pengeluaran kas. Pencatatan dengan dasar cash basis sebenarnya sudah tidak dianjurkan karena informasi yang diberikan tidak akurat. Ikatan Akuntansi Indonesia (IAI) dalam PSAK telah mengharuskan setiap pencatatan untuk menggunakan dasar accrual basis karena informasi yang diberikan lebih akurat. Hal ini dikarenakan pencatatan dilakukan pada saat transaksi terjadi. Gereja X Salatiga yang dalam pencatatannya menggunakan dasar cash basis, ternyata masih menggunakan akun piutang dalam neraca, seperti piutang pegawai, piutang panitia/komisi, dan piutang lainnya. Adanya akun piutang mengakibatkan dasar cash basis yang diterapkan tidak sepenuhnya diterapkan. Karena pada pencatatan cash basis tidak mengakui adanya piutang maupun utang. Dengan mempertimbangkan aturan yang berlaku mengenai basis dasar pencatatan, sebaiknya Gereja X Salatiga menggunakan dasar pencatatan accrual basis seperti yang ditentukan oleh IAI dalam PSAK.

\section{Penerapan Laporan Posisi Keuangan menurut PSAK 45}

Gereja X Salatiga menerapkan laporan posisi keuangan yang sudah sesuai dengan format PSAK 45. Laporan posisi keuangan tersebut menyajikan jumlah aktiva, kewajiban, serta aktiva bersih yang dimiliki gereja dalam dalam satu periode keuangan. Nilai yang disajikan dalam laporan posisi keuangan gereja merupakan nilai per tanggal 31 Desember. Akun yang digunakan pada laporan posisi keuangan juga telah disesuaikan dengan akun-akun dalam PSAK 
45. Akun aktiva yang dibedakan menjadi dua, yaitu jumlah aktiva lancar dan aktiva tetap. Akun aktiva lancar Gereja X Salatiga berisikan kas dan setara kas, serta piutang, sedangkan untuk akun aktiva tetap berisikan peralatan, kendaraan, gedung dan bangunan, beserta dengan akumulasi penyusutannya, dan juga tanah yang dimiliki oleh gereja.

Akun kewajiban juga dibedakan menjadi dua, yaitu kewajiban jangka panjang dan kewajiban lancar. Akun kewajiban lancar hanya berisikan persembahan titipan tertuju dari jemaat untuk membantu jemaat lain yang membutuhkan. Gereja juga memberikan informasi mengenai aktiva bersih yang dibedakan menjadi tiga, yaitu aktiva bersih tidak terikat, aktiva bersih terikat temporer, dan aktiva bersih permanen. Gereja menginformasikan mengenai akun dana abadi, dana cadangan, talangan dana APBG periode ini dan talangan dana APBG periode sebelumnya dalam akun aktiva bersih tidak terikat.

\section{Penerapan Laporan Aktivitas menurut PSAK 45}

Laporan aktivitas Gereja X Salatiga belum sesuai dengan PSAK 45, karena laporan aktivitas Gereja $X$ Salatiga hanya menyediakan informasi mengenai kegiatankegiatan dalam setiap komisi dalam satu periode. Selain informasi mengenai kegiatan setiap komisi, laporan akitivitas Gereja X Salatiga juga memberikan informasi mengenai anggaran yang diterima dari gereja dan anggaran yang diterima dari luar gereja, juga informasi mengenai sisa dana. Anggaran yang diterima dari luar gereja biasanya melalui kegiatan usaha dana. Anggaran yang diterima dari gereja merupakan anggaran yang telah disepakati dalam rapat APBG tahunan gereja. Setiap komisi mempunyai laporan aktivitasnya masing-masing. Informasi yang disediakan sangatlah sederhana serta mudah dipahami oleh pengguna informasi.

Gereja X Salatiga perlu membuat laporan aktivitas secara keseluruhan seperti yang telah diatur oleh PSAK 45. Laporan aktivitas Gereja X Salatiga memberikan informasi mengenai pendapatan dan penghasilan, beban serta pengeluaran gereja. Kelompok akun pendapatan dan penghasilan pada laporan aktivitas dibedakan menjadi dua, yaitu penghasilan dan pendapatan tidak terikat dan penghasilan dan pendapatan terikat. Informasi dalam akun pendapatan dan penghasilan tidak terikat berasal dari persembahan, baik dari persembahan mingguan, persembahan bulanan atau perpuluhan, penghasilan parkir, pendapatan bunga, dan persembahan khusus lainnya. Kelompok akun pendapatan dan penghasilan terikat memuat informasi mengenai dana abadi, kepedulian, PPP-Gereja X, titipan tertuju, bunga deposito, bunga tabungan, dan dana lainnya.

Kelompok akun beban dan pengeluaran terbagi menjadi dua, yaitu beban dan pengeluaran rutin tidak terikat dan, beban dan pengeluaran transitir terikat. Akun beban dan pengeluaran rutin tidak terikat menginformasikan mengenai pengeluaran untuk setiap komisi yang ada di Gereja X Salatiga. Akun beban dan pengeluaran transitis terikat berisikan informasi mengenai dana abadi klasis/sinode, dana IDKK klasis Salatiga, kepedulian sesama, dana beasiswa gereja, dana pembangunan, dan titipan tertuju.

\section{Penerapan Laporan Arus Kas menurut PSAK 45}

Laporan arus kas Gereja X Salatiga belum sesuai dengan PSAK 45. Gereja X Salatiga membuat laporan arus kas dengan format yang sederhana dan dapat dimengerti oleh para pengguna laporan keuangan. Laporan arus kas dibuat dalam bentuk laporan APBG yang terdiri dari dua unsur, yaitu unsur penerimaan kas dan unsur pengeluaran kas disertai dengan realisasi anggaran dan persentase perolehan realisasi anggaran. Laporan APBG juga diberikan informasi mengenai kenaikan dan penurunan dari saldo awal periode. 
Gereja X Salatiga perlu membuat laporan arus kas seperti format yang telah diatur oleh PSAK 45. Laporan arus kas berisikan informasi arus keluar masuknya kas sebuah entitas. Laporan arus kas dibagi menjadi tiga aktivitas, yaitu arus kas dari aktivitas operasi, arus kas dari aktivitas investasi, dan arus kas dari aktivitas pendanaan. Arus kas dari aktivitas operasi memuat informasi mengenai arus kas masuk dan arus kas keluar dari aktivitas utama gereja. Arus kas dari aktivitas operasi berisikan akun-akun persembahan, biaya umum, biaya gaji, biaya lain-lain. Arus kas dari aktivitas investasi memuat informasi mengenai pembelian atau penjualan aset gereja, seperti pembelian kendaraan, pendapatan sewa gedung gereja, dan pembelian peralatan. Arus kas dari aktivitas pendanaan memuat informasi mengenai sumber dana yang diperoleh dari gereja.

\section{Penerapan Catatan Atas Laporan Keuangan menurut PSAK 45}

Catatan Atas Laporan Keuangan yang dibuat oleh Gereja X Salatiga belum sesuai dengan PSAK 45. CALK yang dibuat oleh Gereja X Salatiga digunakan sebagai dasar prediksi penyusunan anggaran atau revisi. Format yang digunakan tidak baku, hanya berupa grafik penerimaan dan pengeluaran kas yang disertai dengan narasi. CALK dipresentasikan pada rapat pleno.

Entitas nirlaba perlu membuat CALK untuk mengetahui perincian akun-akun di laporan keuangan yang ada. Beberapa akun seperti dana abadi perlu dijelaskan lebih rinci lagi sumber dananya serta untuk apa dana tersebut digunakan. Aktiva neto juga perlu diberikan catatan mengenai besar pembatasan yang terpenuhi. GEREJA $X$ Salatiga perlu membuat CALK seperti format yang telah diatur oleh PSAK 45.

\section{Simpulan dan Saran}

\section{Simpulan}

Berdasarkan hasil penelitian, maka dapat diambil kesimpulan bahwa Gereja X
Salatiga pada dasarnya menggunakan metode pencatatan cash basis, namun dalam praktiknya Gereja X Salatiga menggunakan metode accrual basis. Terbukti dengan ditemukannya akun piutang pada laporan posisi keuangan. Untuk pelaporannya, Gereja X Salatiga sudah menerapkan dan membuat laporan keuangan yang sesuai dengan peraturan PSAK 45. Gereja X Salatiga sudah menyajikan laporan posisi keuangan dengan format laporan yang sudah sesuai dengan PSAK 45, namun untuk laporan aktivitas, laporan arus kas dan CALK, Gereja X Salatiga masih menggunakan format tersendiri dan sangat sederhana. Walaupun format laporan keuangan belum sesuai dengan format laporan keuangan dari Ikatan Akuntansi Indonesia, namun secara umum tujuan laporan keuangan Gereja X Salatiga telah tercapai. Laporan keuangan yang disajikan oleh gereja sudah dapat dipahami oleh para pengguna laporan keuangan.

\section{Saran}

Gereja X Salatiga dapat menggunakan accrual basis untuk dasar pencatatannya, karena cash basis sudah tidak dianjurkan IAI dalam PSAK. Untuk pelaporannya, Gereja X Salatiga dapat mempertahankan format laporan keuangan seperti ini, karena laporan keuangan sudah dapat dimengerti dengan para pengguna laporan keuangan. Untuk penelitian berikutnya, disarankan untuk menggunakan ISAK 35 sebagai ganti PSAK 45 yang dicabut pada Januari 2020.

\section{Daftar Pustaka}

Andarsari, P. R. (2017). Laporan Keuangan Organisasi Nirlaba (Lembaga Masjid). Ekonika : Jurnal Ekonomi Universitas Kadiri, 1(2), 143-152. https://doi.org/10.30737/ekonomika.v $1 \mathrm{i} 2.12$ 
Cordery, C. (2015). Accounting For Charities From An International Perspective: a Review Of Principles And Practice In The United Kingdom, The Netherlands, Hong Kong and New Zealand.

Cordery, C. J., Crawford, L., Breen, O. B., \& Morgan, G. G. (2019). International Practices, Beliefs Ind Values In NotFor-Profit Financial Reporting. Accounting Forum, 43(1), 16-41. https://doi.org/10.1080/01559982.201 9.1589906

Dinanti, A., \& Nugraha, G. A. (2018). Pelaporan Keuangan Organisasi Nirlaba. Jurnal Ekonomi, Bisnis, Dan Akuntansi (JEBA), 20, 1-8.

Fatin, N. (2017). Pengertian Organisasi Nirlaba serta Karakteristiknya. Retrieved January 29, 2017,http://seputarpengertian.blogspo t.com/2017/01/pengertian-organisasinirlaba-serta-karakteristiknya.html

Gultom, I., \& Poputra, A. (2015). Analisis Penerapan PSAK No.45 Tentang Laporan Keuangan Organisasi Nirlaba dalam Mencapai Transparansi dan Akuntabilitas Kantor Sinode Gmim. Jurnal Riset Ekonomi, Manajemen, Bisnis Dan Akuntansi, 3(4), 527-537.

Indrianto, N., \& Supomo, B. (2013). Metodelogi Penelitian Bisnis Untuk Akuntansi dan Manajemen (Jilid 1). Yogyakarta: Fakultas Ekonomi dan Bisnis UGM.

Jusuf, A. H. (2005). Dasar-dasar Akuntansi. Yogyakarta: Sekolah Tinggi Ilmu Ekonomi YKPN.

Liadi, P. A. (2011). Rekonstruksi Pelaporan Keuangan Organisasi Nirlaba Pada Panti Asuhan Kanaan Jember Berdasarkan PSAK Nomor 45 (Revisi 2011). Article, 45(REVISI). http://repository.unej.ac.id/bitstream/ handle/123456789/73793/PRISCA

AMELIA

LIADI.pdf;sequence $=1 \% 0 \mathrm{~A}$

Mamesah, M. (2013). Penerapan Psak No.45 Pada Gmim Efrata Sentrum Sonder
Kaitannya Dengan Kualitas Informasi Laporan Keuangan. Jurnal Riset Ekonomi, Manajemen, Bisnis Dan Akuntansi, 1(4), 1717-1728.

Nikmatuniayah. (2014). Penerapan Teknologi Laporan Keuangan Berdasarkan Sak Etap Dan Psak 45 Iai Pada Yayasan Daruttaqwa Kota Semarang. Prosiding SNaPP: Sosial, Ekonomi Dan Humaniora, 1(1), 273 280.

http://proceeding.unisba.ac.id/index.p $\mathrm{hp} /$ sosial/article/view/166/pdf

Pontoh, C. R. S. (2013). Penerapan Laporan Keuangan Organisasi Nirlaba Berdasarkan Psak No 45 Pada Gereja Bzl. Jurnal EMBA: Jurnal Riset Ekonomi, Manajemen, Bisnis Dan Akuntansi, 1(3), 129-139. https://ejournal.unsrat.ac.id/index.php /emba/article/view/1651

Roslan, N., Arshad, R., \& Mohd Pauzi, N. F. (2017). Accountability and Governance Reporting by Non-Profit Organizations. SHS Web of Conferences, 36, 00041. https://doi.org/10.1051/shsconf/20173 600041

Scherp, H. A. (2013). Quantifying Qualitative Data Using Cognitive Maps. International Journal of Research \& Method in Education, 53(9), 67-81. https://doi.org/10.1017/CBO9781107 415324.004

Sousa. (2014). Validation in Qualitative Research: General Aspects and Specificities of the Descriptive Phenomenological Method, Qualitative Research in Psychologu. Qualitative Research in Psychology, 11, 211-227. https://doi.org/10.1080/14780887.201 3.853855

Torang, S. (2013). Organisasi dan Manajemen (Perilaku, Sturktur, Budaya dan Perubahan Organisasi).

Tunungki, A. N. M., \& Pusung, R. J. (2014). Penerapan Laporan Keuangan 
Jurnal Akuntansin Volume 13 Nomor 1, Mei 2021 : 61 - 71

Organisasi Nirlaba Berdasarkan PSAK No.45 pada Panti Sosial Tresna Werdha Hana. EMBA, 2.

U. Sekaran, \& R. Bougie. (2016). Research Method for Business: a Skill-building Approach. Haddington: John Wiley \& Sons.

Yuda, E. (2016). PSAK 45 (Pelaporan Keuangan Organisasi Nirlaba). Retrieved from blogspot.com website: https://feelinbali.blogspot.com/2016/0 7/psak-nomor-45-pelaporankeuangan.html

Yuliarti, N. C. (2014). Studi Penerapam PSAK 45 Yayasan Panti Asuhan Yabappenatim Jember. Jurnal Akuntansi Universitas Jember, 12, 5873.

http://www.ghbook.ir/index.php?nam e= فرهن نوين هاsoption=com_dbook\&task=reado nline\&book_id $=13650 \&$ page $=73 \& \mathrm{ch}$ khashk $=$ ED9C9491B4\&Itemid $=218 \&$ lang=fa\&tmpl=component 